Collection: COST Action FP0903 2010 - Rome (Italy)

"Research, monitoring and modelling in the study of climate change and air pollution impacts on forest ecosystems"

Guest Editors: E Paoletti, J-P Tuovinen, N Clarke, G Matteucci, R Matyssek, G Wieser, R

Fischer, P Cudin, N Pototic

\section{Landscape-scale Ips typographus attack dynamics: from monitoring plots to GIS- based disturbance models}

\author{
Jakus $R^{(1)}$, Zajíčkova $L^{(2)}$, Cudlín $P^{(3)}$, Blaženec $M^{(1)}$, Turčani $M^{(2)}$, Ježík \\ $M^{(1)}$, Lieutier $F^{(4)}$, Schlyter $F^{(5)}$
}

In natural spruce stands, a change of generation is usually initiated by wind or bark beetle disturbances. We combined semi-temporary monitoring plots, remote sensing, and GIS in order to understand and model these processes. Sub plots, called "active", were located in areas with a high probability of bark beetle or wind disturbances. The optimal location of these plots is usually at an active forest edge, i.e., the zone of maximal change in bark beetle abundance over time, corresponding to the border between wind-damaged or bark beetleattacked parts and undisturbed parts of a forest stand. The key variable investigated was tree mortality caused by bark beetles. Other variables were similar to those recorded in traditional forest monitoring. Tree defense indicators (resin flow, phenolic compounds) and reaction of a tree to bark beetle inoculation were measured. Terrestrial data were then combined with remote sensing data. Time series of satellite images were analyzed in order to define the pattern of wind and bark beetle damages. Weather monitoring data were used for predicting bark beetle and water stress development. All of the information was integrated in a GIS-based system and future bark beetle infestations were predicted. In this paper, we review previous studies and conclude that: (1) the hypotheses of habitat selection (non-host volatiles and semiochemical diversity) and location of moderately-stressed host trees are confirmed, although further work about olfactory orientation and host resistance is needed;(2) reactions of trees to bark beetle attack can be predicted by monitoring several parameters, e.g., air temperature and tree physiology; (3) data from ground monitoring can be integrated with GIS and remote sensing systems for bark beetle prognosis and management at the habitat and landscape levels.

Keywords: Spruce, Ips typographus, Attack, Drought, Host

\section{Introduction}

The most important processes of forest stand development are growth and disturbance (Stage 1973). Due to the effect of climatic changes, the role of disturbances is becoming more important (Kurz et al. 2008, Van Mantgem et al. 2009). Storms, drought and warm periods, together with temperature breaks in early spring, are very negative factors for Norway spruce forests, in particular allochthonous populations (e.g., Manion 1981). These events will be more frequent according to most of climate change scenarios. The important natural disturbances in spruce stands are wind and beetles. A significant part of European spruce forests is old with frequent disturbances. A change of generation is usually initiated by wind or bark beetles. The process of decline of an old stand may be relatively fast (Hlásny \& Turčáni 2009). Unfortunately, traditional forest monitoring plots (ICP - Forest level I or National Forest Inventories) focus on mature, managed stands in areas with no disturbances. These types of plot are selected according to their position in a net (e.g., $7 \mathrm{x}$ $7 \mathrm{~km}$ square net). Only few plots are situated in remnants of semi-natural forests, where the consequences of natural disturbances are not solved by forest management.

The main aim of our research was to understand the mechanisms of I. typographus attack on standing spruce, from habitat and host location to host acceptance (Schlyter \& Birgersson 1999). There are two main hypotheses for host location: random landing (Byers 1996), and primary attraction (Gries et al. 1989). Both methods of host location
(1) Institute of Forest Ecology, Slovak Academy of Sciences, Stúrova 2, 96053 Zvolen (Slovakia); (2) Department of Forest Protection and Wildlife Management, Faculty of Forestry and Wood Sciences, Czech University of Life Sciences Prague, Kamýcká 1176, 16500 Praha-Suchdol (Czech Republic); (3) Institute of Systems Biology and Ecology, Academy of Sciences of the Czech Republic, Na Sádkách 7, 37005 Ceské Budejovice (Czech Republic); (4) University of Orleans, LBLGC, UPRES EA 1207, rue de Chartres, BP 6759, F-45067 Orleans Cedex 2 (France); (5) Chemical Ecology, Department of Plant Protection Biology, Swedish University of Agricultural Sciences (SLU), PO Box 102, SE-230 53 Alnarp (Sweden)

\section{@, Rastislav Jakus (rasti.jakus@gmail.com)}

Received: Dec 23, 2010 - Accepted: Apr 26, 2011

Citation: Jakus R, Zajíčkova L, Cudlín $\mathrm{P}$, Blaženec $M$, Turčani $M$, Ježík $M$, Lieutier $F$, Schlyter F, 2011. Landscape-scale Ips typographus attack dynamics: from monitoring plots to GIS-based disturbance models. iForest 4: 256-261 [online 2011-1213] URL:

http://www.sisef.it/iforest/contents/? id=ifor0589-004

can be seen as subsequent steps after habitat (stand) selection, a behavior which is likely a balance of a positive input from the host (conifer) kairomone and a negative input from non-host (angiosperm broad-leaves) volatiles, or NHV (Zhang \& Schlyter 2004). Such "semiochemical diversity" at the habitat level (Zhang \& Schlyter 2003) may affect both herbivores and predators (Zhang \& Schlyter 2010). Host acceptance is connected with host recognition, resistance and suitability (Raffa et al. 2008), which in turn are connected to tree health (Christiansen et al. 1987) and ecophysiology (Nelson \& Lewis 2008).

Führer et al. (1997) demonstrated that attacks of I. typographus occur on vigorously growing trees suffering from a sudden stress. This may be explained by a lack of constitutive defense in fast growing trees, combined with a stress-induced failure in the induction of secondary defense mechanisms. In endemic conditions, I. typographus attacks downed trees on sun-exposed slopes with open canopy (Jakuš 1995). According to Raffa et al. (2008), the tree-killing bark beetle species display flexible host-selection strategies. When the populations are low, avoiding healthy trees is an adaptive mechanism. Vigorous trees pose a risk to beetles 
Tab. 1 - Parameters measured in the monitoring plots of projects focused on bark beetle spruce interactions (Tatry, Spiš, Kysuce and Kyrill).

\begin{tabular}{|c|c|c|c|c|}
\hline \multirow{2}{*}{ Characteristic } & \multicolumn{4}{|c|}{ Project } \\
\hline & Tatry & Spiš & Kysuce & Kyrill \\
\hline Soil and environment & - & - & - & - \\
\hline Root regeneration potential & $*$ & - & - & - \\
\hline Mycorrhizal status & $*$ & - & - & - \\
\hline Fungi occurrence & $*$ & - & - & - \\
\hline Soil water potential & - & - & + & $*$ \\
\hline Soil water content & - & - & - & $*$ \\
\hline Air temperature & $*$ & - & - & - \\
\hline Meteorological data & - & $*$ & $*$ & $*$ \\
\hline Dendrometry & - & - & - & - \\
\hline DBH & $*$ & $*$ & $*$ & $*$ \\
\hline Dendrochronological analysis & $*$ & - & - & - \\
\hline Circumference changes & - & $*$ & $*$ & $*$ \\
\hline Tree health & - & - & - & - \\
\hline Defoliation & $*$ & $*$ & - & - \\
\hline Primary structure defoliation & $*$ & $*$ & - & $*$ \\
\hline Photosynthesis & $*$ & - & - & - \\
\hline Needle water content & $*$ & - & - & - \\
\hline Phenolic content & $*$ & - & - & - \\
\hline Sap flow & - & $*$ & $*$ & $*$ \\
\hline Needle temperature & - & $*$ & $*$ & - \\
\hline Bark temperature & - & $*$ & $*$ & - \\
\hline Photosynthetic pigments content & - & - & - & $*$ \\
\hline Proline content & - & - & - & * \\
\hline Monoterpene emission & - & - & - & $*$ \\
\hline Bark beetle population & - & - & - & - \\
\hline Tree mortality & $*$ & * & $*$ & - \\
\hline Pheromone trap catch & $*$ & - & - & - \\
\hline Ips typographus boring experiments & - & - & $*$ & * \\
\hline
\end{tabular}

because of their superior defenses. Physiologically compromised trees pose a lower risk, but are sparsely distributed in space, ephemeral in time, and nutritionally suboptimal. In the first stage of the outbreak in mountainous conditions (incipient epidemic population), I. typographus predominantly uses wind-thrown trees, mostly on fresh forest edges (spot initialization), as in endemic conditions. Once populations increase, the discriminating behavior becomes less adaptive, because of the greater likelihood of recruiting enough beetles to overcome healthy trees. Once beetles have successfully killed a tree, because of low tree resistance and/or high beetle population, they may rapidly switch to the closest trees (Anderbrant et al 1988). Such trees may likely become foci of aggregation and could be killed regardless of their resistance level. Vigorous trees provide a largely vacant resource, and in general are the most suitable for beetles' nutrition, because of their thick phloem. Beetles are more likely to attack trees adjacent to the already initialized spots (Jakuš et al. 2003a). Sun-exposed slopes or sites are susceptible to $I$. ty pographus attack regardless of the gradation phase and stand conditions (Jakuš et al. 2003b, Grodzki et al. 2006, Akkuzu et al. 2009). This indicates that questions of sun radiation and shading are important for understanding the mechanisms of I. typographus host selection.

The working hypothesis in the case of standing trees is that the I. typographus pioneer male locates and/or accepts the most susceptible host spruce trees (Moravec et al. 2002). The process of attack is initialized by a disturbance, such as wind throw or bark beetle related mortality, which usually results in removal of neighboring trees or their foliage. The remaining trees are suddenly exposed to direct solar radiation. In the case of dense stands with short tree crowns, large parts of the stem will in turn be exposed to the sun, increasing transpiration and water stress. Resistance of a tree to bark beetle would then be diminished. Higher temperatures on the sun-exposed bark would increase emission of bark beetle primary attractants (Baier \& Bader 1997). The question of host resistance at a different scale is thus important. At the scale of an individual tree, tree physiology (Nelson \& Lewis 2008) and secondary chemistry are likely the most important factors addressing host resistance (Urbanek Krajnc et al. 2010, Zhao et al. 2010). At the scale of habitats and landscapes, GIS-based modeling may help in understanding bark beetle damage.

The aim of this paper is to summarize the main results of our previous work on this issue and synthesize the progress of knowledge.

\section{Ground-level research and study plots}

We developed a semi-temporary monitoring pair plots approach to understand and model processes of bark beetle-caused spruce mortality at the forest stand scale. Generally, the active plots were located in areas with a high probability of bark beetle or wind caused disturbances, because of proximity to wind destroyed or bark beetle attacked areas. The control plots were situated in undisturbed forest stands $(<50 \mathrm{~m}$ from the active plots).

\section{Project Tatry (1999-2001)}

The project "Integrated risk assessment and new pest management technology in ecosys tems affected by forest decline and bark beetle outbreaks (TATRY)" was conducted in natural spruce forests affected by bark beetle in the Tatra Mountains (Schlyter 2001, Grodzki et al. 2006, 2010).

\section{Plot design}

An altitudinal transect was established including 5 pairs of monitoring plots, located between 1000 and $1400 \mathrm{~m}$ a.s.1. at a $100 \mathrm{~m}$ altitude interval. Each pair consisted of one active plot (60 trees) on the stand edge or bark beetle spot, and one control plot (30 trees) within the forest stand. The plots were visited several times a year in order to identify trees that were attacked by bark beetles (Grodzki et al. 2003). The measured or monitored variables are shown in Tab. 1. In addition, beetle chemoreception of trees and habitat was studied in the field and laboratory (Zhang \& Schlyter 2004).

\section{Main results}

Main results reported here are from Schlyter (2001). (1) Relatively healthy trees, i.e., recovering after a damage, with high defoliation of the primary crown and high percentage of secondary shoots, were more susceptible to beetle attack than those with a low defoliation of the primary crown and a low percentage of secondary shoots (Polák et al. 2007). (2) Phenolic predictors of tree resistance against fungal attacks were also good predictors for tree resistance against bark beetle attacks in the field (Lieutier et al. 2003). Three such phenolic predictors (catechin, taxifolin, and resveratrol) were shown to be anti-feedant semiochemicals for bark 
beetle (Faccoli \& Schlyter 2007), thus affecting host acceptance. (3) A model for bark beetle development in relation to temperature was developed and tested (Netherer \& Pennerstorfer 2001, Netherer \& Noppmayr 2005). (4) For the first time, information about NHV blends was used for forest protection in the field (Jakuš et al. 2003b).

\section{Project Spiš (2003-2006)}

The project "Analysis of causes and possible measures against mass die-back of spruce stands in border regions of north Slovakia" was conducted in planted spruce forests affected by chronic decline and bark beetle attacks (Jakuš 2001).

\section{Plot design}

An altitudinal transect was established, including 3 pairs of monitoring plots located between 740 and $1100 \mathrm{~m}$ a.s.l. Each pair consisted of one active plot (30 trees) on the stand edge or bark beetle spot in the fores and one control plot (30 trees) within the forest stand. The plots were visited several times a year in order to identify trees that were attacked by bark beetles. The measured or monitored variables are shown in Tab. 1.

\section{Main results}

Main reported here are from Jakuš (2006). Trunk cooling by transpiration flow is an important mechanism of tree protection against overheating. Our results showed differences in the cooling abilities of sun-exposed parts on sunny days. The level of overheating was higher in trees attacked by bark beetles than healthy trees, because higher defoliation leads to slower transpiration flow.

\section{Project Kysuce (2005-2008)}

The project was carried out in planted spruce forests affected by chronic decline and bark beetle attacks.

\section{Plot design}

Two mini plots were established, each consisting of three spruce trees. In one plot, drought stress was simulated using a shelter to prevent root access to precipitation. The second plot was used as a control. Sap flow, stem circumference and soil water potentia were measured. Air temperature, air relative humidity, global radiation, and precipitation were measured in an open area. Bark beetle boring abilities were tested on the monitored trees (Turčáni \& Nakládal 2007). The measured or monitored variables are shown in Tab. 1.

\section{Main results}

Only slight differences in sap flow rates between the plots were recorded, suggesting that only small differences in soil water regime can be achieved by sheltering precipitation to the tree roots. As a result, the bark beetle boring responses were also unclear (Turčáni \& Nakládal 2007).

\section{Project Kyrill (2008-2011)}

The project "Study and optimization of real efficiency of control measures against Ips typographus in various gradation phases" investigated the role of drought as a main driving factor of bark beetle outbreaks (Zajickova \& Matousek 2010).

\section{Plot design}

Two large-scale research areas were established. A large roof at $2 \mathrm{~m}$ above the ground level and isolation of the root system from side ground water inflow controlled the water regime. Different physiological reactions of the drought stressed trees can be induced by decreasing soil water potential. The first research area "Brdy" was located at $650 \mathrm{~m}$ a.s.l., with 6 drought-stressed trees and 12 control trees. Tree response to drought was monitored by dendrometers and soil water potential sensors. A manipulation experiment with adult male beetles, testing the willingness of males to enter the phloem and create a nuptial chamber, was performed in 2008 and 2009. There are two critical factors for such experiments: (i) a large number of male beetles in good health and (ii) suitable weather conditions at the time of the experiment. The second research area "Kostelec" was located at $350 \mathrm{~m}$ a.s.l. in a Norway spruce monoculture, with two drought-stressed and two control plots $(25 \mathrm{~m}$ x $25 \mathrm{~m}$ ). Physiology of four trees was monitored by dendrometers and sampling needles for proline analysis. The "Kostelec" experiment began in 2010 .

\section{Main results}

Main results reported here are from Zajickova \& Matousek (2010). (1) Trees exposed to enhanced drought did not show any resin flow when conducting the manipulation experiment with male beetles at the beginning of an enhanced drought in 2008. In 2009, the response level of the defense system of the tree was higher, and flow of resin was recorded in each nuptial chamber. We concluded that the level of drought stress affects pest resistance of the tree. (2) During dry periods, drought-stressed trees showed no changes in stem circumference, while they showed the same values of stem diameter change as control trees during rainy periods.

\section{Remote sensing and GIS based research}

Project Tatry (1999-2001)

\section{Methods}

Vegetation change analysis, digital elevation model, and stand characteristics were integrated in the remote sensing part of this study. Time series of LANDSAT images were used in this study (Jakuš et al. 2003a).

\section{Main results}

Main results reported here are from Jakuš et al. (2003a). The spatial pattern of the spread of bark beetle outbreaks was related to the phase of the outbreak and insolation (incoming solar radiation). Progression of the attacks arose mainly from initiation of new bark beetle spots. In the culmination and retrogradation phases, outbreaks spread by further expansion from old spots. The spots spread in all directions except south (forest edge oriented to north). We recorded a time-dependence in the decrease of distances between old and new spots. In the first stage of the outbreak, the beetles migrated over fairly long distances. At later stages, the available resources were more limited, thus the beetles were more likely to attack resources adjacent to old spots even though they were less suitable.

\section{Project SLOVABBO (2003-2004)}

The results of project Tatry were used for developing a first version of a GIS and remote sensing based early warning system for bark beetle infestations (Kissiyar et al. 2005). The results were used in the TANABBO model (Tatra National Park Bark Beetle Outbreak - the name of the model is different from the project acronym).

\section{Methods and main results}

Main results reported here are from Jakuš et al. (2005) and Kissiyar et al. (2005). A rating system for assessing the predisposition of forests to bark beetle attack was developed on the basis of known causal relationships between bark beetle outbreak and environmental parameters. A system of sub models was used. Each sub model produced a certain output that was then used in the model. A one-year prognosis of bark beetle attack was based on modeling of the two processes connected with the spread of a bark beetle outbreak: spot initialization and spot spreading (Jakuš et al. 2003a). The actual risk of beetle attack was estimated by means of a bark beetle development model (Netherer \& Pennerstorfer 2001, Baier et al. 2007), i.e., a vegetation health model derived from MODIS satellite images and a drought index based on soil characteristics, precipitation data, and potential evapotranspiration.

\section{Discussion}

\section{Semi-temporary monitoring pair plots}

The approach of semi-temporary monitoring pair plots was used in several studies and was helpful in investigating the mechanisms of I. typographus attack on spruce. The combination of traditional monitoring 
plots with semi-temporary monitoring pair plots helped to better understand the mechanism of bark beetle related disturbances Results showed that I. typographus mostly attacks moderately stressed, "resilient" trees sensu Polák et al. (2007). The whole sequence of mechanisms is still unclear, in particular about host location and attack (habita location, host location, host acceptance, overcoming of defenses). Interestingly, while no "primary attraction" sensu strictu (Anderson 1948) has been proven, the sensory array of I. typographus includes many receptors for host monoterpenes (Andersson et al 2009, Andersson et al. 2010). The defense at tree and stand scales may be explained by water stress (project Kyrill).

\section{Tree thermal properties and water stress}

Hais \& Kučera (2008) showed that surface temperature in a spruce forest is strongly influenced by topography; slope and aspect influence potential radiation and heat load. Higher surface temperatures can be expected at forest edges during clear sky conditions in summer. Part of the I. typographus attack mechanism is connected with the effects of solar radiation and surface temperatures on individual trees (project Spiš) and forest stands (Jakuš et al. 2003B, Grodzki et al. 2006, Akkuzu et al. 2009). This is also in agreement with Schopf \& Köhler (1995).

Drought predisposes spruce to bark beetle attack. Questions related to water stress were studied in projects Spis and Kysuce in mountain conditions. We did not obtain clear results due to the variability of the natural conditions. In contrast, project Kyrill provided evidence in support of the role of water stress in predisposing spruce to $I$. ty pographus attack.

Thermal sensing is a proxy of insolation and water stress effects on trees. According to Jones \& Schofield (2008), it is primarily used to study plant water relations and specifically stomatal conductance, because a major determinant of leaf temperature is the rate of evaporation or transpiration from the leaf. The cooling effect of transpiration arises because a substantial amount of energy is required to convert liquid water to water vapor.

\section{Tree health and host resistance}

The results of project Tatry also showed the importance of parameters related to spruce crown transformation and host resistance, in accordance with Moravec et al. (2002). Malenovský et al. (2008) suggested the use of remote sensing for mapping crown transformation. One type of markers of spruce host resistance are phenolic compounds (Brignolas et al. 1998), which may affect host colonization (Schlyter 2001) and are active as antifeedant semiochemicals
(Faccoli \& Schlyter 2007). According to Soukupová et al. (2001), it is possible to assess the content of phenolic compounds in spruce needles with the use of remote sensing techniques.

\section{Key variables}

Our research suggests that several variables related to I. typographus attack can be measured in ground plots and used for modeling bark beetle disturbances via GIS. The main variables are indicators of water stress (sap flow, stem diameter) and the surface temperature of trees or stands. In addition, crown transformation and phenolic content are also recommended as possible variables to be measured.

\section{Practical applications}

The knowledge gained during project Tatry on the anti-attractant and semiochemical diversity effects of NHV (Zhang \& Schlyter $2003,2004)$ is now being put into practice for forest protection (Jakuš et al. 2003b, Jactel et al. 2011, Schiebe et al. 2011). The results from GIS and remote sensing application were used for decision making in NP Tatry (Schlyter 2001, Grodzki et al. 2006) and NP Sumava (Turčáni et al. 2008).

\section{Conclusions}

1. Our observations and experiments confirmed the hypotheses of habitat selection (non-host volatiles and semiochemical diversity) and location of moderately-stressed host trees, although further work about olfactory orientation (to habitat cues and host odor) and host resistance is needed.

2. Reactions of trees to bark beetle attack can be predicted by monitoring several parameters, e.g., air temperature and tree physiology.

3. Data from ground monitoring can be integrated with GIS and remote sensing systems for bark beetle prognosis and management at the habitat and landscape levels.

\section{Acknowledgements}

We thank C. Schiebe, Alnarp, for comments on an earlier draft. The Slovak participation was supported by the project implementation: Centrum of excellence of biological methods of forest protection (ITMS: 26220120008), supported by the Research \& Development Operational Programme funded by the ERDF. Experimental work during the Tatry project was supported by grants from the Swedish Council for Forestry and Agricultural Research (SJFR: \#23.0521:96 and \#24.0293:98) and an EU-INCO project (CT 98-0151). FS was funded by FORMAS project \#230-2005-1778 "Semiochemical diversity and insect dynamics", the Linnaeus program "Insect chemical ecology, ethology, and evolution $\left(\mathrm{ICE}^{3}\right)$, and by the Department of Plant Protection Biology, SLU, Alnarp.
Joint publication of the COST Action FP0903 Climate Change and Forest Mitigation and Adaptation in a Polluted Environment. Keith Edwards improved the English.

\section{References}

Akkuzu E, Sariyildiz T, Kucuk M, Duman A (2009). Ips typographus (L.) and Thanasimus formicarius (L.) populations influenced by aspect and slope position in Artvin-Hatila valley national park, Turkey. African Journal of Biotechnology 8: 877-882.

Anderbrant O, Schlyter F, Lofqvist J (1988). Dynamics of tree attack in the bark beetle Ips typographus under semi-epidemic conditions. In: "Integrated control of scolytid bark beetles" (Payne TK, Saarenmaa H eds). Virginia Tech Press, Blacksburg, VA, USA, pp. 35-52.

Anderson RF (1948). Host selection by the pine engraver. Journal of Economic Entomology 41: 596-602.

Andersson M, Larsson MC, Blazenec M, Zhang QH, Jakuš R, Schlyter F (2010). Peripheral modulation of pheromone response by inhibitory host compound in a beetle. Journal of Experimental Biology 213 (19): 3332-3339. - doi: 10.1242/jeb.044396

Andersson MN, Larsson MC, Schlyter F (2009). Specificity and redundancy in the olfactory system of the bark beetle Ips typographus: singlecell responses to ecologically relevant odors. Journal of Insect Physiology 55 (6): 556-567. doi: 10.1016/j.jinsphys.2009.01.018

Baier P, Bader R (1997). Gehalt und emission von monoterpenen der fichtenrinde und deren bedeutung für die primärattraktion von borkenkäfern (Coleoptera, Scolytidae). Mitteilungen der Deutschen Gesellschaft fur Allgemeine und Angewandte Entomologie 11: 639-643.

Baier P, Pennerstorfer J, Schopf A (2007). PHENIPS -A comprehensive phenology model of Ips typographus (L.) (Col., Scolytinae) as a tool for hazard rating of bark beetle infestation. Forest Ecology and Management 249 (3): 171186. - doi: 10.1016/j.foreco.2007.05.020

Brignolas F, Lieutier F, Sauvard D, Christiansen E, Berryman AA (1998). Phenolic predictors for Norway spruce resistance to the bark beetle Ips typographus (Coleoptera : Scolytidae) and an associated fungus, Ceratocystis polonica. Canadian Journal of Forest Research 28: 720-728. doi: 10.1139/x98-037

Byers J (1996). An encounter rate model of bark beetle populations searching at random for susceptible host trees. Ecological Modelling 91 (13): 57-66. - doi: 10.1016/0304-3800(95)00166-2 Christiansen E, Waring RH, Berryman AA (1987). Resistance of conifers to bark beetle attack: searching for general relationships. Forest Ecology and Management 22 (1-2): 89-106. doi: 10.1016/0378-1127(87)90098-3

Faccoli M, Schlyter F (2007). Conifer phenolic resistance markers are bark beetle antifeedant semiochemicals. Agricultural and Forest Entomology 9 (3): 237-245. - doi: 10.1111/j.1461-9563. 2007.00339.x 
Führer E, Lindenthal J, Baier P (1997). Tree mortality in spruce: relationships between the premortal tree vigour dynamics and attack by bark-breeding insects. Mitteilungen der Deutschen Gesellschaft fur Allgemeine und Angewandte Entomologie 11: 645-648. [in German].

Gries G, Nolte R, Sanders W (1989). Computer simulated host selection in Ips typographus. Entomologia experimentalis et applicata 53 (3): 211-217. - doi: 10.1111/j.1570-7458.1989. tb03568.x

Grodzki W, Jakuš R, Gazda M (2003). Patterns of bark beetle occurrence in Norway spruce stands of national parks in Tatra Mts Poland and Slovakia. Journal of Pest Science 76 (3): 78-82. - doi: 10.1046/j.1439-0280.2003.03018.x

Grodzki W, Jakuš R, Lajzová E, Sitková Z, Maczka T, Skvarenina J (2006). Effects of intensive versus no management strategies during an outbreak of the bark beetle Ips typographus (L.) (Col.: Curculionidae, Scolytinae) in the Tatra Mts. in Poland and Slovakia. Annals of Forest Science 63 (1) : 55-61. - doi: 10.1051/ forest:2005097

Grodzki W, Turčáni M, Jakuš R, Hlásny $T$, Raši R, McManus M (2010). Bark beetles in the Tatra Mountains. International research 1998 - 2005 an overview. Folia Forestalia Polonica 52: 114 130.

Hais M, Kučera T (2008). Surface temperature change of spruce forest as a result of bark beetle attack: remote sensing and GIS approach. European Journal of forest Research 127 (4): 327-336. - doi: 10.1007/s10342-008-0208-8

Hlásny T, Turčáni M (2009). Insect pests as climate change driven disturbances in forest ecosystems. In: "Bioclimatology and natural hazards" (Strelcová K, Mátyás C, Kleidon A, Lapin M, Matejka F, Blaženec M, Skvarenina J, Holécy J eds). Springer, The Netherlands, pp. 165-177. - doi: 10.1007/978-1-4020-8876-6_15 Jactel H, Birgersson G, Andersson S, Schlyter F (2011). Non-host volatiles mediate associational resistance to the pine processionary moth. Oecologia 166 (3): 703-711. - doi: 10.1007/s00442011-1918-Z

Jakuš R (1995). Bark beetle (Coleoptera: Scolytidae) communities and host and site factors on tree level in Norway spruce primeval natural forest. Journal of Applied Entomology 119: 643 $-651$.

Jakuš R (2001). Bark beetle (Coleoptera: Scolytidae) outbreak and system of IPM measures in area affected by intensive forest decline connected with honey fungus (Armillaria sp.). Journal of pest science 74: 46 - 51 .

Jakuš R, Grodzki W, Ježik M, Jachym M (2003a). Definition of spatial patterns of bark beetle Ips typographus (L.) outbreak spreading in Tatra Mountains (central Europe), using GIS. In: "Ecology, survey and management of forest insects" (Mc Manus M, Liebhold A eds). Proceedings of the conference GTR NE-311, USDA Forest Service, Newtown Square, PA, USA, pp. 25-32.

Jakuš R, Schlyter F, Zhang Q-H, Blazenec M, Vavercák R, Grodzki W, Brutovský D, Lajzová
E, Bengtsson M, Blum Z, Turcáni M, Gregoiré JC (2003b). Overview of development of anti-attractant based technology for spruce protection against Ips typographus: from past failures to future success. Journal of Pest Science 76 (4): 8999. - doi: 10.1046/j.1439-0280.2003.03020.x

Jakuš R, Ježik M, Kissiyar O, Blaženec M (2005). Prognosis of bark beetle attacks in TANABBO model. In: "GIS and databases in the forest protection in Central Europe" (Grodzki W ed). Forest Reseach Institute, Krakow, Poland, pp. 35-43.

Jakuš R (2006). Analysis of causes and possible measures against mass dieback of spruce stands in border regions of north Slovakia. Final Research Report from the Project APVT-51019302, Institute of forest ecology, SAS Zvolen, pp. 195. [In Slovak]

Jones HG, Schofield P (2008). Thermal and other remote sensing of plant stress. General and Applied Plant Physiology 34: 19-32.

Kissiyar O, Blaženec M, Jakuš R, Willekens A, Ježík M, Baláž P, Van Valckenborg J, Celer S, Fleischer P (2005). TANABBO model - A remote sensing based early warming system for forest decline and bark beetle outbreaks in Tatra Mts. -overview. In: GIS and databases in the forest protection in Central Europe (Grodzki W ed). Forest Reseach Institute, Krakow, Poland, pp. 15-34.

Kurz W, Dymond C, Stinson G, Rampley G, Neilson E, Carroll A, Ebata T, Safranyik L (2008). Mountain pine beetle and forest carbon feedback to climate change. Nature 452 (7190): 987-990. - doi: 10.1038/nature06777

Lieutier F, Brignolas F, Yart A, Grodski W, Jakuš R, Sauvard D (2003). Field validation of phenolics as predictors of Norway spruce resistance to Ips typographus attacks during a finishing outbreak. In: Proceedings of the IUFRO Working Party Meeting "Forest insect population dynamics and host influences". Kanazawa (Japan) 14-19 September 2003, pp. 14-19.

Malenovský Z, Martin E, Homolova L, Gastellu-Etchegorry J, Zurita-Milla R, Schaepman M, Pokorný R, Clevers J, Cudlin P (2008). Influence of woody elements of a Norway spruce canopy on nadir reflectance simulated by the DART model at very high spatial resolution. Remote Sensing of Environment 112 (1): 1-18. - doi: 10.1016/j.rse.2006.02.028

Manion PD (1981). Tree disease concepts. Prentice-Hall, Englewood Cliffs, NJ, USA, pp. 399.

Moravec I, Cudlín P, Polák T, Havlíček F (2002). Spruce bark beetle (Ips typographus L.) infestation and Norway spruce status: is there a causal relationship? Silva Gabreta 8: 255-264.

Nelson W, Lewis M (2008). Connecting host physiology to host resistance in the conifer-bark beetle system. Theoretical Ecology 1 (3): 163177. - doi: 10.1007/s12080-008-0017-1

Netherer S, Pennerstorfer J (2001). Parameters relevant for modelling the potential development of Ips typographus (Coleoptera: Scolytidae). Integrated Pest Management Reviews 6 (3-4): 177 184. - doi: 10.1023/A:1025719301446
Netherer S, Noppmayr U (2005). Predisposition assessment systems (PAS) as supportive tools in forest management-rating of site and stand-related hazards of bark beetle infestation in the High Tatra Mountains as an example for system application and verification. Forest Ecology and Management 207 (1): 99-107. - doi: 10.1016/j. foreco.2004.10.020

Polák T, Cudlin P, Moravec I, Albrechtova J (2007). Macroscopic indicators for the retrospective assessment of Norway spruce crown response to stress in the Krkonoše Mountains. Trees - Structure and Function 21 (1): 23-35. doi: 10.1007/s00468-006-0093-Z

Raffa K, Aukema B, Bentz B, Carroll A, Hicke J, Turner M, Romme W (2008). Cross-scale drivers of natural disturbances prone to anthropogenic amplification: the dynamics of bark beetle eruptions. Bioscience 58 (6): 501-517. - doi: 10.1641 /B580607

Schiebe C, Blazenec M, Jakus R, Unelius CR, Schlyter F (2011). Semiochemical diversity diverts bark beetle attacks from Norway spruce edges. Journal of Applied Entomology - doi: 10.1111/j.1439-0418.2011.01624.x

Schlyter F, Birgersson G (1999). Forest beetles. In: "Pheromones in non-lepidopteran insects associated with agricultural plants" (Hardie J, Minks AK eds). CAB International, Oxford, UK, pp. 113-148.

Schlyter F (2001). Integrated risk assessment and new pest management technology in ecosystems affected by forest decline and bark beetle outbreaks "TATRY". Final report of EU INCO Copernicus project IC15-CT98-0151 2001. [online] URL: http://www-vv.slu.se/fs/tatry/fin_rapp/FR_ Outl.htm

Schopf R, Köhler U (1995). Untersuchungen zur populationsdynamik der fichtenborkenkäfer im nationalpark bayerischer Wald. In: "Nationalpark Bayerischer wald-25 jahre auf dem weg zum naturwald" (Biberlriether $\mathrm{H}$ ed). Passavia Druckerei GmbH, Passau, Germaby, pp. 88-110.

Soukupová J, Rock B, Albrechtová J (2001). Comparative study of two spruce species in a polluted mountainous region. New Phytologist 150 (1): 133-145. - doi: 10.1046/j.1469-8137. 2001.00066.x

Stage AR (1973). Prognosis model for stand development. Research Paper INT-137, Intermountain Forest and Range Experiment Station, USDA Forest Service, Ogden, Utah, pp. 40.

Turčáni M, Nakládal O (2007). The results of manipulated experiments with inoculation of Ips typographus (L., 1758) to spruce trees under various levels of water stress. Journal of Forest Science 53: 25-30.

Turčáni M, Vojtech O, Jakuš R (2008). Bark beetle influencing on forest ecosystems. In: "Forest ecosystems in NP Sumava" (Vacek S, Krejči F, Grodzki W eds). Lesnícka Práce, Czech Republic, pp. 325-412.[In Czech].

Urbanek Krajnc A, Kristl J, Ivancic A (2010). Application of salicylic acid induces antioxidant defense responses in the phloem of Picea abies and inhibits colonization by Ips typographus. Forest 
Ecology and Management 261 (3): 416-426. doi: $10.1016 / j$.foreco.2010.10.027

Van Mantgem P, Stephenson N, Byrne J, Daniels L, Franklin J, Fule P, Harmon M, Larson A, Smith J, Taylor A (2009). Widespread increase of tree mortality rates in the western United States. Science 323 (5913): 521-524. - doi: 10.1126/science. 1165000

Zajickova L, Matousek P (2010). The effect of drought on stem volume changes of Norway spruce. Scientia Agriculturae Bohemica (in the press)
Zhang QH, Schlyter F (2003). Redundancy, synergism, and active inhibitory range of non-host volatiles in reducing pheromone attraction in European spruce bark beetle Ips typographus. Oikos 101 (2): 299-310. - doi: 10.1034/j.16000706.2003.111595.x

Zhang QH, Schlyter F (2004). Olfactory recognition and behavioural avoidance of angiosperm non-host volatiles by conifer bark beetles. Agricultural and Forest Entomology 6 (1): 1-20. doi: 10.1111/j.1461-9555.2004.00202.x

Zhang QH, Schlyter F (2010). Inhibition of pre- dator attraction to kairomones by non-host plant volatiles for herbivores: a bypass-trophic signal. PLoS One 5: e11063. - doi: 10.1371/journal.pone. 0011063

Zhao T, Krokene P, Björklund N, Långström B, Solheim H, Christiansen E, Borg-Karlson AK (2010). The influence of Ceratocystis polonica inoculation and methyl jasmonate application on terpene chemistry of Norway spruce, Picea abies. Phytochemistry 71 (11-12): 1332-1341. doi: 10.1016/j.phytochem.2010.05.017 